\title{
HIV infection and hepatic enzymes abnormalities: A hospital based study among the HIV infected women of India
}

\author{
Soumitra Barick ${ }^{1}$, Sandip Chattopadhyay ${ }^{2, *}$, Nirmalya Kumar Sinha ${ }^{3}$, Bulbul Purkait ${ }^{4}$
}

${ }^{\mathbf{1}}$ Research Scholar, ${ }^{\mathbf{2}}$ Assistant Professor, ${ }^{\mathbf{3}}$ Part Time Teacher, ${ }^{\mathbf{4}}$ Associate Professor, ${ }^{\mathbf{1}, 2}$ Dept. of Bio-Medical Laboratory Science and Management, ${ }^{3}$ Dept. of Nutrition, ${ }^{4}$ Dept. of Biochemistry, ${ }^{\mathbf{1 , 2}}$ Vidyasagar University, Midnapore, West Bengal, ${ }^{3}$ Raja N.L. Khan Women's College, Midnapore, West Bengal, ${ }^{4}$ Midnapore Medical College \& Hospital, Midnapore, West Bengal, India

*Corresponding Author:

Email: sandipdoc@mail.vidyasagar.ac.in

\begin{abstract}
Introduction: Globally HIV infection has become a serious public health problems as it is responsible for millions of deaths every year and the women are the most vulnerable to HIV infection in the developing and underdeveloped countries. The liver enzymes alteration is a useful indicator of the HIV severity of the body. This study was designed to find the effect of $\mathrm{CD}_{4}$ count and nutritional status on liver enzymes among $\mathrm{HIV}^{+}$and $\mathrm{HIV}^{-}$women living in West Bengal.

Materials and Methods: This hospital based cross sectional study was performed among 97 women at Midnapore Medical College and Hospital, Midnapore, India. Blood samples were collected from the participants to determine $\mathrm{CD}_{4}$ count, Serum glutamate oxaloacetate transaminase (SGOT), serum glutamic pyruvate transaminase (SGPT), and alkaline phosphates (ALP). Anthropometric measurements were taken using the standard techniques

Results: $\mathrm{HIV}^{-}$women $\left(20.42 \pm 1.763 \mathrm{~kg} / \mathrm{m}^{2}\right)$ were significantly heavier $(\mathrm{t}=4.172 ; \mathrm{P}<0.001)$ than the $\mathrm{HIV}^{+}$one $\left(18.52 \pm 2.63 \mathrm{~kg} / \mathrm{m}^{2}\right)$. Similarly the HIV ${ }^{-}$women $(995.92 \pm 100.24$ cells $/ \mu \mathrm{l})$ had higher level of $\mathrm{CD}_{4}$ than the $\mathrm{HIV}^{+}$women $(374.22 \pm 185.66 \mathrm{cells} / \mu \mathrm{l})$ at significant level $(\mathrm{t}=20.459 ; \mathrm{P}<0.001)$. The Odd ratio indicated that the elevated SGPT, SGOT and ALP were $1.250,1.520$ and 14.400 times higher among the $\mathrm{HIV}^{+}$than $\mathrm{HIV}^{-}$women.

Discussion: HIV-infected women are at a greater risk of abnormal liver function and this abnormality increases with the severity of the disease condition.
\end{abstract}

Keywords: CD4 count, Antiretroviral therapy, Human immunodeficiency virus infection, Liver function.

\section{Introduction}

HIV/AIDS (Human immunodeficiency virus/ acquired immunodeficiency syndrome) is responsible for 35 million deaths so far. ${ }^{1}$ Recent reports revealed that nearly 36.7 million people were living with HIV infection and nearly 1.8 million people have been newly infected in 2016 throughout the globe. ${ }^{1}$ Another report stated that 17.8 million women were living with HIV infection which is 51 percent of the total adult people with HIV infection throughout the world. ${ }^{2}$ However, in 1985, only $35 \%$ of the infected people were women. ${ }^{3}$ The drastically increasing rate of HIV infection among the women are varied from region to region such as in sub-Saharan Africa it was $60 \%$ while in Caribbean it was $45-50 \%$. The low increasing rate was seen in Asia and Latin America (30-40\%), and Eastern Europe and Central Asia (30\%). ${ }^{4}$ It is also estimated that the 2.5 million people living with HIV/AIDS in India, of which nearly $40 \%$ were women. ${ }^{5}$ The dramatic increase of the HIV infection among the women is due to the biological vulnerabilities, poor socioeconomic states, and dominant sexual practice of males. The other cause of the HIV infection among the women is transmission of HIV infection from the male partners having risky sexual behavior during occupational migration. ${ }^{5}$

$\mathrm{HIV}^{+}$women faced many social, psychological problems. HIV infection causes systemic disease with many complications. ${ }^{6}$ In HIV infection, liver enzymes are elevated due to altered liver functioning in response to pathogenic invasion. ${ }^{7-8} \mathrm{HIV}$-infected persons may reproduce hepatitis $\mathrm{B}(\mathrm{HBV})$ or hepatitis $\mathrm{C}(\mathrm{HCV})$ infection due to opportunistic infection in them and induce liver enzyme abnormalities, which are very common among $\mathrm{HIV}^{+}$than those of $\mathrm{HIV}^{-}$individuals. ${ }^{9}$ ${ }^{10}$ In HIV-HBV co-infections, HIV infection causes increased rates of persistent HBV infection, increased cirrhosis and liver related mortality and increased risk of hepatocellular carcinoma at lower CD4+ counts. ${ }^{11}$ Similarly in HIV-HCV co-infections, there is a more rapid progress to cirrhosis, end-stage liver disease and hepatocellular carcinoma. ${ }^{12}$ The liver fibrosis pathogenesis, nonalcoholic fatty liver disease and nonalcoholic steatohepatitis may have a direct impact on the further progression of liver disease. ${ }^{13-14}$ Several studies suggest that mortality was higher in HIVinfected patient's with elevated liver enzymes than that of HIV-uninfected patients with liver function abnormalities. ${ }^{15-16}$ It is well known that undernutrition is predominant among the $\mathrm{HIV}^{+}$individuals and it is also related with the liver enzyme abnormalities among $\mathrm{HIV}^{-}$individuals. So, this study examines the effect of $\mathrm{CD}_{4}$ count and nutritional status on liver enzymes among $\mathrm{HIV}^{+}$and $\mathrm{HIV}^{-}$women living in West Bengal.

\section{Materials and Methods}

This hospital based cross sectional study was performed at Midnapore Medical College and Hospital, Midnapore, India. The suspected individuals came for medical treatment in this hospital as a first point of 
contact. The women participants were randomly selected and the study group was consisting of 97 women of which 49 were $\mathrm{HIV}^{+}$.

Prior to the study Institutional ethical permission was obtained. The objective of the study was explained to the probable participants and those who consented were included in the study.

Anthropometric measurements were taken using the standard techniques. ${ }^{17}$ Height was measured to the nearest $0.1 \mathrm{~cm}$ using Martin's anthropometer. Body weight of the lightly-clothed participants was recorded in the nearest $0.1 \mathrm{~kg}$ on a digital weighing scale. Body mass index (BMI) was computed using the standard equations and nutritional status was assessed by internationally accepted BMI guidelines. ${ }^{18}$

Blood samples were collected from the participants in Dept. of Biochemistry, Midnapore Medical College and Hospital. A $5 \mathrm{ml}$ of blood sample was collected from each participant of which, $3 \mathrm{ml}$ of blood was collected in a sterile test tube and allowed to clot and centrifuged at 3,000 rpm for 10 minutes to separate the serum for estimation of liver enzymes. Serum glutamate oxaloacetate transaminase (SGOT), serum glutamic pyruvate transaminase (SGPT), and alkaline phosphates (ALP) were estimated by semi auto analyzer (Biochemistry Analyzer-ErbaChem 5 Plus). The remaining $2 \mathrm{ml}$ of blood was used for CD4 lymphocyte count, which was estimated by Fluorescence Activated Cell Sorter (FACS) count system. Blood glucose of the participants was measured by glucose assay kit employing the glucose oxidase and peroxidase method.

The data were analyzed using Statistical Package (SPSS, version 17), data were presented as number (percentage) or mean $\pm \mathrm{SD}$ as appropriate. The Student's $\mathrm{t}$ test was done to compare the mean differences in BMI, $\mathrm{CD}_{4}$ count among the $\mathrm{HIV}^{+}$and $\mathrm{HIV}^{-}$women. The differences in means of the liver enzymes in $\mathrm{HIV}^{-}$ and different categories of $\mathrm{HIV}^{+}$based on CD4 count were compared using One-Way Analysis of Variance (ANOVA) and Dunnett test. The $\chi^{2}$ test was also performed to study the elevation of liver enzymes in various categories. The level of significance was determined at 5 percent $(\mathrm{p}<0.05)$.

\section{Results}

In the present study, the mean age of female participants was $29.80 \pm 7.78$ years and the BMI was $19.46 \pm 2.43 \mathrm{~kg} / \mathrm{m}^{2}$. While comparing the BMI of the $\mathrm{HIV}^{+}$and $\mathrm{HIV}^{-}$women, it was observed that $\mathrm{HIV}^{-}$ women $\left(20.42 \pm 1.763 \mathrm{~kg} / \mathrm{m}^{2}\right)$ were significantly heavier $(\mathrm{t}=4.172 ; \mathrm{P}<0.001)$ than the $\mathrm{HIV}^{+}$one $(18.52 \pm 2.63$ $\mathrm{kg} / \mathrm{m}^{2}$ ). Similar finding was observed in case of CD4 count, the $\mathrm{HIV}^{-}$women $(995.92 \pm 100.24$ cells $/ \mu \mathrm{l})$ had higher level of $\mathrm{CD}_{4}$ than the $\mathrm{HIV}^{+}$women $(374.22 \pm 185.66$ cells $/ \mu 1)$ at significant level $(t=20.459$; $\mathrm{P}<0.001)$. The overall prevalence of undernutrition among the females were $26.80 \%$ while in case of $\mathrm{HIV}^{+}$ and $\mathrm{HIV}^{-}$women these were $40.82 \%$ and $12.50 \%$ respectively. The liver enzymes studied in this investigation were SGPT, SGOT and ALP. Table 1 indicates that ALP was negatively correlated with $\mathrm{CD}_{4}$

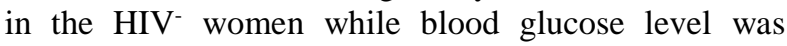
positively correlated with SGPT and SGOT but no such association was observed in $\mathrm{HIV}^{+}$women. It was found that BMI and ALP was significantly different in various categories of $\mathrm{CD}_{4}$ (Fig 1). The lower prevalence of undernutrition and elevated ALP was observed among $\mathrm{HIV}^{-}$women than those of $\mathrm{HIV}^{+}$women while $\mathrm{HIV}^{+}$ women with $\mathrm{CD}_{4} \quad 300-500$ showed the highest prevalence of these abnormalities (Fig 2). In figure 3 the liver enzymes showed the different distribution pattern with respect to $\mathrm{BMI}$ and $\mathrm{CD}_{4}$.

Table 1: Correlation between liver enzymes and nutritional status among HIV positive and negative female

\begin{tabular}{|l|c|c|c|c|}
\hline HIV status & Indices & SGPT & SGOT & ALP \\
\hline \multirow{3}{*}{ HIV $^{+}$} & BMI & 0.108 & 0.109 & -0.022 \\
\cline { 2 - 5 } & CD4 & -0.052 & 0.228 & 0.121 \\
\cline { 2 - 5 } & Blood glucose & 0.185 & 0.055 & 0.055 \\
\hline \multirow{3}{*}{ HIV $^{-}$} & BMI & 0.182 & 0.135 & 0.052 \\
\cline { 2 - 5 } & CD4 & -0.166 & -0.226 & $-0.329^{*}$ \\
\cline { 2 - 5 } Total & Blood glucose & $0.322^{*}$ & $0.390^{* *}$ & 0.116 \\
\cline { 2 - 5 } & BMI & 0.064 & 0.047 & -0.190 \\
\cline { 2 - 5 } & CD4 & -0.154 & -0.09 & $-0.403 * * *$ \\
\cline { 2 - 5 } & Blood glucose & $0.201 *$ & 0.161 & -0.011 \\
\hline
\end{tabular}




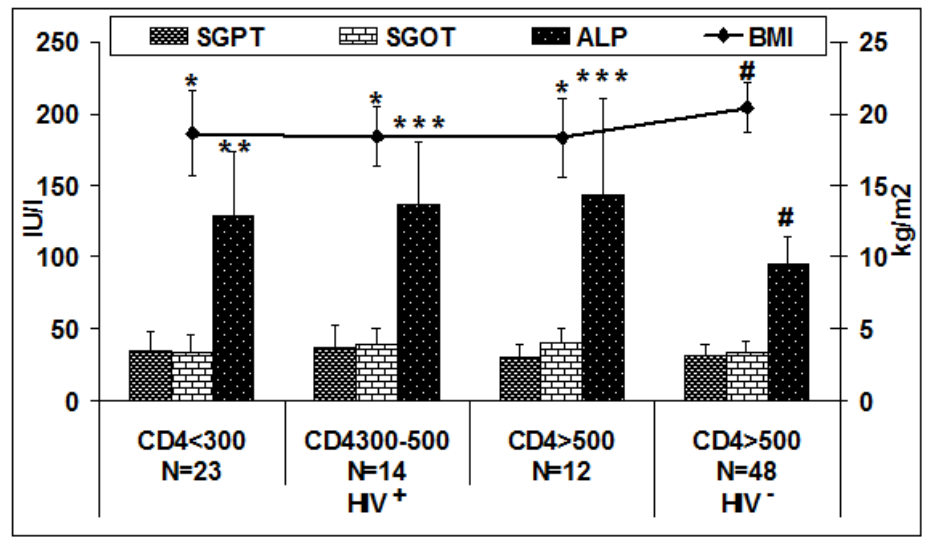

Fig. 1: Mean and standard deviation of the SGPT, SGOT, ALP and BMI with varied CD4 level. \# indicates the significant difference in the variables with CD4 levels (ANOVA test) and Post hoc test indicates the level of significance at $* \mathbf{P}<0.05, * * \mathbf{P}<0.01, * * * \mathbf{P}<0.001$ while compared to the HIV group

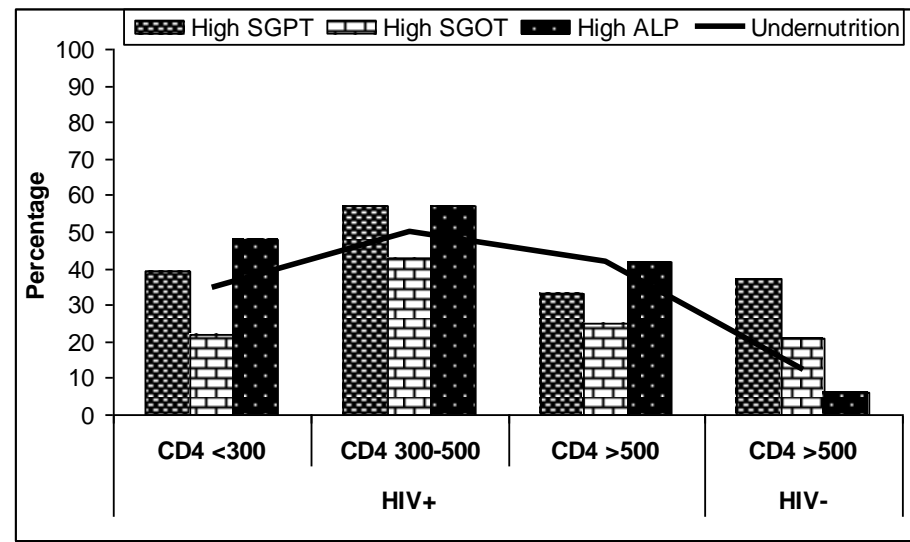

Fig. 2: Impact of CD4 count on the liver enzymes and nutritional status among $\mathrm{HIV}^{+}$and HIV $\mathrm{Hemale}^{-}$ Prevalence of high ALP $\left(\chi^{2}=22.839 ; P<0.001\right)$ and undernutrition $\left(\chi^{2}=10.943 ; P<0.05\right)$ was associated with CD4 level in $\mathrm{HIV}^{+}$and HIV- female
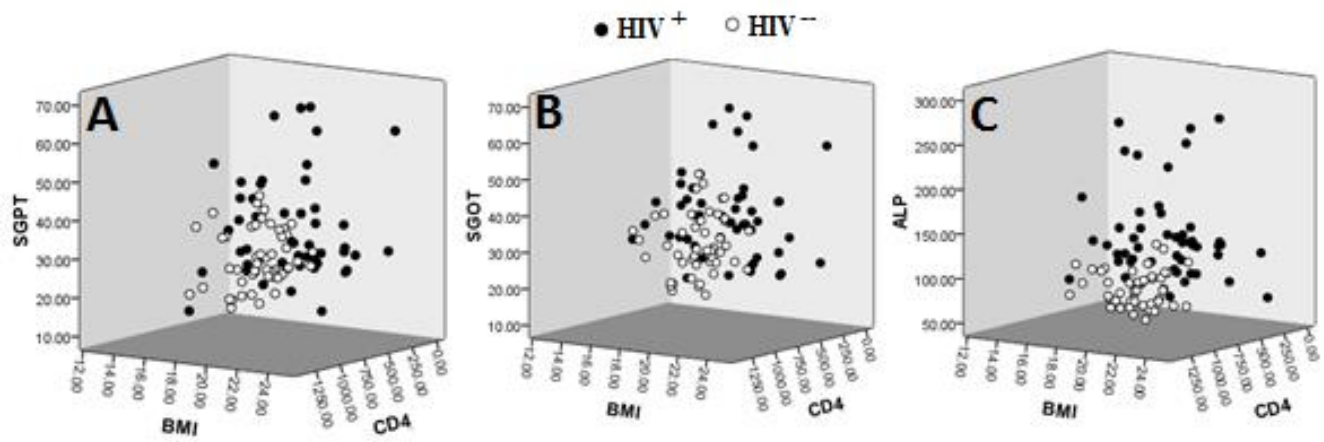

Fig. 3: Scatter plot explore the distribution of SGPT, SGOT, ALP on varied CD4, BMI among $\mathrm{HIV}^{+}$and HIV female

\section{Discussion}

In this study, the high prevalence of undernutrition (40.82\%) among the $\mathrm{HIV}^{+}$women was noted. This may be due to the HIV infection induced malabsorption ${ }^{19}$ and lower food intake ${ }^{19}$ while increasing nutrients demands during HIV infection (10\% more energy in asymptomatic and 20-30\% more energy in symptomatic condition). ${ }^{20}$ The elevation of the hormones glucagon, insulin, epinephrine, and cortisol is associated with altered metabolism of carbohydrates, proteins, and fat during HIV infection and thereby promotes rapid weight loss. ${ }^{21}$

It was also noticed that liver enzymes (mainly ALP) significantly increased in $\mathrm{HIV}^{+}$women compared with the $\mathrm{HIV}^{-}$women. The SGOT $(34.51 \pm 13.24$ vs $31.63 \pm 7.52)$ and SGPT $(36.78 \pm 12.12$ vs $33.65 \pm 8.14)$ were higher among the $\mathrm{HIV}^{+}$women than the $\mathrm{HIV}^{-}$ 
women though the change is insignificant. While studying this elevation level, it was noted that prevalence of elevated SGPT among the $\mathrm{HIV}^{+}$and $\mathrm{HIV}^{-}$women was $42.86 \%$ and $37.50 \%$ respectively and in case of ALP $(48.98 \%$ and $6.25 \%)$ and SGOT (28.57\% and $20.83 \%)$ similar higher prevalence was noted in HIV+ women than those of HIV- women. The Odd ratio indicated that the elevated SGPT, SGOT and ALP were 1.250, 1.520 and 14.400 times higher among the $\mathrm{HIV}^{+}$than $\mathrm{HIV}^{-}$women. It may be suggested that the HIV infection is associated with the abnormalities of liver enzymes. HIV infects a wide range of nonhematopoietic cells, including cells in the liver. ${ }^{22} \mathrm{HIV}$ infection directly attacks host cells and operate the infected cells. These infected cells release cellular contents into the surrounding medium of which enzymes constitute $20 \%$ and this may also one of the most importance causes of elevation of liver enzymes. ${ }^{23}$ The other probable mechanism of the pathogenesis of liver damage is that the whole body protein increases which is related to the progression of the HIV infection in the body and the downfall of CD4 count. Some studies suggest that HIV can alter the permeability of the gastrointestinal tract, leading to increased levels of circulating lipopolysaccharide that may affect liver function parameters, ${ }^{24}$ and in advanced HIV infection, there is an elevated rate of protein turnover. ${ }^{25}$ The other studies suggested that circulating cytokines including tumor necrosis factor (TNF), interleukin (IL)-6, and interferon (IFN)- $\alpha$ etc. are increased during HIV infection and these have a direct effect on protein metabolism. ${ }^{25,26}$ Other probable causes of this increased serum enzymes are hepatitis, drug toxicity, extrahepatic cholestasis, cirrhosis, hepatobiliary disease, and genetic abnormalities. ${ }^{23}$

\section{Conclusion}

It can be concluded from this study that HIV infection might be responsible for elevation of liver enzymes in $\mathrm{HIV}^{+}$women and the ALP showed the higher level of alteration of all the liver enzymes. This elevation of liver enzymes abnormalities is associated with CD4 counts before the initiation of ART treatment.

\section{Acknowledgement}

The part of the work is funded by UGC Innovative Research Project (SC) [VU/Innovative/SC/01/2015 dated 17.06.2018]

\section{References}

1. WHO. HIV/AIDS Fact sheet: http://www.who.int/mediacentre/factsheets/fs360/en. July2017.

2. UNWOMEN. Facts and figures: HIV and AIDS. http://www.unwomen.org/en/what-we-do/hiv-andaids/facts-and-figures. 2018.
3. Dworkin SL, Ehrhardt AA. Going beyond "ABC" to include "GEM": critical reflections on progress in the HIV/AIDS epidemic. Am J Public Health 2007;97:13-8.

4. UNAIDS/WHO. AIDS Epidemic Update. [Online]. 2008. http:// www.unaids.org/en/KnowledgeCentre/HIVData/GlobalR eport/2008/ [accessed 30 April 2009].

5. Mothi SN, Lala MM, Tappuni AR. HIV/AIDS in women and children in India. Oral Dis. 2016; 22 (Suppl. 1):1924.

6. Morse CG, Kovacs JA. Metabolic and skeletal complications of HIV infection: The price of success. JAMA. 2006;296(7):844-854.

7. Pol S, Lebray P, Vallet-Pichard A. HIV infection and hepatic enzyme abnormalities: Intricacies of the pathogenic mechanisms. Clin Infect Dis. 2004;38(Suppl 2):S65-72.

8. Nunez M. Hepatotoxicity of antiretrovirals: Incidence, mechanisms and management. J Hepatol. 2006;44(1 Suppl):S132-139.

9. Zechini B, Pasquazzi C, Aceti A. Correlation of serum aminotransferases with HCV RNA levels and histological findings in patients with chronic hepatitis C: The role of serum aspartate transaminase in the evaluation of disease progression. Eur J Gastroenterol Hepatol. 2004;16(9):891-896.

10. Sterling RK, Sulkowski MS. Hepatitis C virus in the setting of HIV or hepatitis B virus coinfection. Semin Liver Dis. 2004;24(Suppl 2):61-68.

11. Thio CL. Hepatitis B and human immunodeficiency virus coinfection. Hepathol. 2009;49(5):138-145.

12. Romeo R, Rumi M, Donato M, Cargne P, Vigano M, Mondelli B. Hepatitis C is more severe in drug users with human immunodeficiency virus infection. J Viral Hepathol. 2000;7:297-301.

13. Ingiliz P, Valantin MA, Duvivier C, et al. Liver damage underlying unexplained transaminase elevation in human immunodeficiency virus-1 mono-infected patients on antiretroviral therapy. Hepatol. 2009;49(2):436-442.

14. Crum-Cianflone N, Dilay A, Collins G, et al. Nonalcoholic fatty liver disease among HIV-infected persons. J Acquir Immune Defic Syndr. 2009;50(5):464473.

15. Ruhl CE, Everhart JE. Elevated serum alanine aminotransferase and gamma-glutamyltransferase and mortality in the United States population. Gastroenterol. 2009;136(2):477-485.

16. Koethe JR., Blevins M., Nyirenda C, et al. Nutrition and inflammation serum biomarkers are associated with 12 week mortality among malnourished adults initiating antiretroviral therapy in Zambia. J Int AIDS Soc. 2011;14:19.

17. Lohman TG, Roche AF, Martorell R. Anthropometric standardization reference manual. Champaign, IL. Human Kinetics Books. 1988.

18. World Health Organization. Physical Status: The Use and Interpretation of Anthropometry. Technical Report Series 854. Geneva: World Health Organization. 1995.

19. Mitiku A, Ayele TA, Assefa M, Tariku A. Undernutrition and associated factors among adults living with Human Immune Deficiency Virus in Dembia District, northwest Ethiopia: an institution based cross-sectional study. Arch Public Health. 2016;74:33.

20. Hadgu TH, Worku W, Tetemke D, Berhe H. Undernutrition among HIV positive women in Humera hospital, Tigray, Ethiopia, 2013: antiretroviral therapy alone is not enough, cross sectional study. BMC Public Health. 2013;13:943. 
21. Young J. HIV and medical nutrition therapy. J Am Diet Assoc. 1997;10:S161-7.

22. Megan C, David I, Sharon RL. Human Immunodeficiency Virus and the liver. World J Hepatol. 2012;4(3):91-98.

23. Pasupathi P, Bakthavathsalam G, Saravanan G, Devaraj A. Changes in $\mathrm{CD} 4+$ cell count, lipid profile and liver enzymes in HIV infection and AIDS patients. J Appl Biomed. 2008;6:139-145.

24. Crane M, Iser D, Lewin SR: Human immunodeficiency virus infection and the liver. World J Hepatol 2012;4(3):91-98.

25. Macallan DC, Griffin GE. Metabolic disturbances in AIDS. N Engl J Med 1992;327(21):1530-1531.

26. Breen EC, Rezai AR, Nakajima K, et al. Infection with HIV is associated with elevated IL-6 levels and production. J Immunol 1990;144(2):480-484. 